\title{
HSPH1 Gene
}

National Cancer Institute

\section{Source}

National Cancer Institute. HSPH1 Gene. NCI Thesaurus. Code C116974.

This gene plays a role in the unfolded protein response. 